\title{
Efektivitas Model Pembelajaran Guided-Inquiry terhadap Kemampuan Berpikir Kritis dan Pemecahan Masalah
}

\author{
Reginaldis Isabella Sado ${ }^{1}$, Daud Dakabesi ${ }^{2}$, Tien Aminatun ${ }^{3}$ \\ 1,3Pendidikan Biologi-Universitas Negeri Yogyakarta \\ ${ }^{2}$ Pendidikan Kimia-Universitas Negeri Yogyakarta
}

\begin{tabular}{|c|c|}
\hline INFO ARTIKEL & ABSTRAK \\
\hline Riwayat Artikel: & $\begin{array}{l}\text { Abstract: The purpose of this study was to determine the effectiveness of guided- } \\
\text { inquiry model on critical thinking skills and problem solving about material changes in }\end{array}$ \\
\hline 019 & the environment. This research was done by using quasi-experiment with post-test only \\
\hline Disetujui: 23-06-2020 & design. Besides, this research used four research classes that are the experiment two \\
\hline Kata kunci: & $\begin{array}{l}\text { is given the treatment of conventional model. The population used in this study was } \\
\text { tenth grade students of science major at SMAN } 2 \text { Ngaglik, that is chosen randomly. }\end{array}$ \\
\hline $\begin{array}{l}\text { guided-inquiry; } \\
\text { critical thinking; } \\
\text { solution to problem; } \\
\text { environmental change; }\end{array}$ & $\begin{array}{l}\text { Data collection techniques used are test and observation. The results showed that the } \\
\text { guided-inquiry model improved critical thinking and problem solving skills. This is } \\
\text { based on the results of test data analysis which shows a significant difference between } \\
\text { students in the experimental class and student class control. }\end{array}$ \\
\hline
\end{tabular}

Abstrak: Tujuan penelitian ini adalah mengetahui efektivitas model guided-inquiry pada keterampilan berpikir kritis dan pemecahan masalah tentang perubahan materi di lingkungan. Penelitian ini dilakukan dengan menggunakan eksperimen semu dengan desain post-test only. Selain itu, penelitian ini menggunakan empat kelas penelitian, yaitu dua kelas eksperimen yang diberi perlakuan model guided-inquiry dan dua kelas kontrol yang diberi perlakuan model konvensional. Populasi yang digunakan dalam penelitian ini adalah siswa kelas X MIPA di SMAN 2 Ngaglik yang dipilih secara acak. teknik pengumpulan data yang digunakan adalah tes dan observasi. Hasil penelitian menunjukkan bahwa model guided-inquiry meningkatkan kemampuan berpikir kritis dan pemecahan masalah. Hal tersebut didasari oleh hasil uji analisis data yang menunjukkan bahwa adanya perbedaan yang signifikan antara siswa pada kelas eksperimen dan kelas kontrol.

\author{
Alamat Korespondensi: \\ Reginaldis Isabella Sado \\ Pendidikan Biologi \\ Universitas Negeri Yogyakarta \\ Jl. Colombo No.1 Kec. Depok, Kab. Sleman, Daerah Istimewa Yogyakarta \\ E-mail: isabellareginaldis@gmail.com
}

Perkembangan abad 21 menuntut perubahan dalam berbagai bidang, salah satunya adalah pendidikan. Pendidikan memiliki peranan penting dalam menghasilkan sumber daya manusia yang memadai untuk terlibat dalam tuntutan perkembangan abad 21 yang serba dinamis dan kompleks. Sumber daya manusia yang dihasilkan di suatu lembaga pendidikan diharapkan dibekali dengan berbagai keterampilan yang sangat diperlukan dalam dunia kerja. Oleh karena itu, sekolah sebagai salah satu lembaga pendidikan harus menyediakan dan menyelenggarakan kurikulum yang berbasis pada tuntutan perkembangan abad 21. Keterampilan yang sangat dibutuhkan dalam menghadapi perkembangan abad 21 yaitu keterampilan berpikir kritis dan keterampilan memecahkan masalah (Özyurt, 2015). Keterampilan berpikir kritis dan keterampilan memecahkan masalah merupakan keterampilan esensial yang secara langsung berkontribusi pada keberhasilan akademik dan profesional (Greiff, Holt, \& Funke, 2013).

Kemampuan berpikir kritis sangat diperlukan zaman ini karena begitu banyaknya informasi yang beredar yang belum jelas kebenarannya sehingga menuntut setiap manusia untuk berpikir kritis dalam mencari kebenaran informasi. Menurut (Stephenson \& Sadler-Mcknight, 2016) kemampuan berpikir kritis sudah harus diterapkan dalam pembelajaran di bangku sekolah menengah sehingga akan membantu pelajar dalam mempersiapkan diri sehingga nantinya dapat sukses di perguruan tinggi dan tempat kerja (Wartono, Hudha, \& Batlolona, 2018). Selain keterampilan berpikir kritis, siswa juga harus diajarkan keterampilan memecahkan masalah sehingga mampu berpikir secara kompleks dan mendalam untuk memecahkan masalahmasalah yang berkaitan dengan kehidupannya. Kemampuan berpikir kritis dan keterampilan memecahkan masalah merupakan keterampilan berpikir tingkat tinggi yang proses berpikirnya melibatkan domain kognitif analisis, evaluasi, sintesis, dan mencipta. Pentingnya kedua keterampilan ini menjadi fokus utama syarat dalam mempekerjakan orang (Rodzalan \& Saat, 2015). 
Kemampuan berpikir kritis merupakan proses kognitif kompleks yang melibatkan interaksi antara pengetahuan, niat, dan keterampilan pelajar dengan skenario sekitarnya (Yu, Lin, \& Chang, 2017). Kemampuan berpikir kritis merupakan merupakan proses kognitif yang menggunakan penilaian nalar terhadap bukti, konteks, standar, metode, dan struktur konseptual sebagai dasar untuk percaya dan melakukan suatu tindakan dan fokus pada apa yang harus dilakukan (Jatmiko et al., 2018). Kemampuan berpikir kritis merupakan proses penilaian regulasi diri yang mendorong pemecahan masalah dan pengambilan keputusan mengenai apa yang harus dipercayai dalam konteks tertentu. Definisi yang digunakan dalam penelitian ini mengenai kemampuan berpikir kritis adalah proses kognitif yang melibatkan pemikiran tingkat tinggi kaitannya dengan berpikir reflektif, memutuskan tindakan yang cepat dan tepat serta membuat kesimpulan berdasarkan fakta atau kenyataan yang ada dilingkungan untuk memecahkan setiap permasalahan. Kemampuan berpikir kritis adalah kemampuan untuk berpikir secara logis, reflektif dan produktif yang diaplikasikan dalam menilai situasi untuk membuat pertimbangan dan keputusan yang baik. Kemampuan berpikir kritis artinya merefleksikan permasalahan secara mendalam, mempertahankan pikiran agar tetap terbuka bagi berbagai pendekatan dan perspektif yang berbeda, tidak mempercayai begitu saja informasi-informasi yang datang dari berbagai sumber (lisan atau tulisan), serta berpikir secara reflektif ketimbang hanya menerima ide-ide dari luar tanpa adanya pemahaman dan evaluasi yang signifikan. Kemampuan berpikir kritis adalah aktivitas terampil yang dapat dilakukan dengan lebih baik atau sebaliknya, dan pemikiran kritis yang baik akan memenuhi beragam standar intelektual, seperti kejelasan, relevansi, kecukupan, koherensi. Kemampuan berpikir kritis menuntut interpretasi dan evaluasi terhadap observasi, komunikasi dan sumber-sumber informasi lainnya. Keterampilan memecahkan masalah merupakan suatu aktivitas terampil dalam menentukan atau memutuskan suatu tindakan terhadap permasalahan yang ada (Lopez, Shavelson, Nandagopal, Szu, \& Penn, 2014).

Pentingnya kemampuan berpikir kritis dan keterampilan memecahkan masalah sebagai modal untuk menghadapi tuntutan perkembangan zaman ternyata tidak diterapkan dengan baik oleh lembaga pendidikan di Indonesia (Mundilarto, 2012). Berdasarkan studi awal yang dilakukan Rosyid, Jatmiko \& Supardi (2013), menunjukkan bahwa kemampuan berpikir siswa sekolah menengah masih rendah karena dalam proses pembelajaran masih berjalan satu arah atau hanya ada transfer pengetahuan dari guru ke siswa sehingga siswa kesulitan dalam membangun pengetahuannya sendiri. Sejalan dengan temuan di atas, menunjukkan bahwa sebagian besar siswa Indonesia hanya mampu mengenali sejumlah fakta dasar dan belum mampu berkomunikasi dan mengaitkan berbagai topik sains, terutama dalam menerapkan konsep yang kompleks dan abstrak. Selain lemahnya kemampuan berpikir kritis, studi yang dilakukan (Noh, Jeon, \& Huffman, 2009) menunjukkan bahwa meskipun kemampuan pemecahan masalah adalah tujuan utama dalam kursus sains, banyak studi menunjukkan bahwa bahkan setelah pembelajaran, banyak siswa masih mengalami kesulitan memecahkan masalah dan terus menggunakan teknik pemecahan masalah pemula daripada teknik pemecahan masalah yang lebih maju.

Biologi merupakan mata pelajaran yang masuk dalam rumpun sains. Sains merupakan mata pelajaran alam yang dapat membantu individu bertahan dalam dunia saintifik dan teknologi yang selalu berubah (Shishigu, Hailu, \& Anibo, 2018). Sebagai salah satu mata pelajaran yang diajarkan, Biologi memiliki berbagai materi yang diharapkan untuk dapat dipahami oleh siswa, salah satunya adalah materi perubahan lingkungan. Perubahan lingkungan sangat erat kaitannya dengan kehidupan siswa sehari-hari. Dengan demikian, harapannya bahwa materi ini dapat dipahami dengan baik oleh siswa. Namun, seringkali siswa tidak memahami akan materi ini dan bahkan hanya belajar tentang teori-teori yang telah ada. Materi perubahan lingkungan seharusnya adalah sebagai materi yang melatih kemampuan siswa dalam berpikir kritis dan memecahkan masalah. Hal ini dikarenakan materi ini berkaitan dengan dunia nyata siswa yang mana telah terjadi banyak perubahan.

Tantangannya memang bagi pendidik untuk merancang pembelajaran baru dan kurikulum yang mendorong motivasi dan kemandirian sehingga untuk membekali siswa dengan keterampilan belajar, berpikir, dan memecahkan masalah (Tan, 2003); (Mundilarto, 2012); (Wartono et al., 2018). Belajar biologi sangat erat kaitannya dengan penyelidikan, sehingga sudah seharusnya dalam proses pembelajaran guru mengadakan kegiatan praktikum untuk membuktikan teori yang sudah ada. Laboratorium adalah komponen penting dari pendidikan sains yang dapat menumbuhkan sikap positif dan minat terhadap sains. Siswa dapat belajar tidak hanya konsep ilmiah, tetapi juga kemampuan berpikir ilmiah, dan keterampilan eksperimental. Berdasarkan penjelasan di atas, (Nariman \& Chrispeels, 2015) dalam studinya mengatakan bahwa proses pembelajaran yang dirancang guru harus berfokus kepada siswa. Perangkat pembelajaran yang dapat meningkatkan kemampuan berpikir kritis dan keterampilan memecahkan masalah siswa adalah model pembelajaran (Wartono et al., 2018). Model pembelajaran yang berpusat pada siswa, kegiatan pembelajarannya berkaitan dengan kegiatan penyelidikan dan berbasis pada masalah kehidupan nyata siswa, mampu meningkatkan kemampuan berpikir kritis dan keterampilan memecahkan masalah adalah model pembelajaran guided-inquiry (Simanjuntak, Elvis Napitupulu, Manullang, Manalu, \& Sinambela, 2019); (Kitot, Ahmad, \& Seman, 2010); (Hein, 2012).

Model pembelajaran guided-inquiry termasuk dalam pembelajaran konstruktivistik (Chase, Pakhira, \& Stains, 2013); (Hein, 2012); (Conway, 2014). Pembelajaran konstruktivistik pada dasarnya menyatakan bahwa pengetahuan tidak dapat ditransfer dari satu orang ke orang lain (Hmelo-Silver, Duncan, \& Chinn, 2007); pengetahuan harus secara aktif dibangun oleh pelajar melalui interaksi dengan lingkungan (Domin, 1999). Pernyataan seperti itu menyiratkan bahwa sifat lingkungan sama pentingnya dengan karakteristik pembelajar ketika datang untuk mendidik individu, dan mengubah lingkungan dapat menyebabkan hasil belajar yang berbeda. Strategi inkuiri terbagi menjadi empat tingkatan, yaitu menunjukkan, terstruktur, dibimbing, dan inkuiri terbuka (Koksal \& Berberoglu, 2014). Implementasi keempat tingkatan ini dibedakan oleh sejauh mana keterlibatan guru dalam proses pembelajaran. Terlihat bahwa keterlibatan para guru sebagian besar terjadi selama inkuiri yang 
ditunjukkan, dan para guru kurang terlibat dalam inkuiri terstruktur dan guided-inquiry. Keterlibatan paling sedikit guru dalam pembelajaran inkuiri terjadi dalam inkuiri terbuka. Penelitian ini akan menggunakan model pembelajaran guided-inquiry. Kegiatan berbasis penyelidikan bersifat induktif, memiliki hasil yang tidak ditentukan, dan mengharuskan siswa untuk membuat prosedur mereka sendiri (MacKay \& Wetzel, 2014); (Douglas \& Chiu, 2012). Siswa lebih banyak terlibat (Carneiro, Parulekar, Shridhar, \& Ladage, 2016), mengandung lebih sedikit arahan, dan memberi siswa lebih banyak tanggung jawab untuk menentukan pilihan prosedural daripada format tradisional (Douglas \& Chiu, 2012). Pendekatan ini secara efektif memberikan kepemilikan siswa atas kegiatan laboratorium yang menghasilkan siswa menunjukkan peningkatan sikap terhadap instruksi ilmu pengetahuan (Conway, 2014). Kegiatan laboratorium berdasarkan permintaan juga telah ditemukan untuk meningkatkan kemampuan siswa untuk memanfaatkan pemikiran operasional formal. Sintaks atau langkah dalam model pembelajaran guidedinquiry yang digunakan dalam penelitian ini ada enam tahapan, yaitu mengarahkan siswa untuk terlibat dalam pembelajaran, menampilkan masalah atau pertanyaan, merumuskan hipotesis, mengumpulkan data, membuat kesimpulan, dan melakukan refleksi (Arends, 2011).

Penelitian yang dilakukan Koksal \& Berberoglu (2014) menunjukkan bahwa siswa dalam kelas eksperimen yang diajarkan menggunakan model pembelajaran guided-inquiry memiliki dampak positif pada karakteristik kognitif dan afektif. Model pembelajaran guided-inquiry mampu meningkatkan pemahaman siswa tentang konsep sains dan sikap (Conway, 2014) serta minat siswa terhadap sains. Temuan serupa dikemukakan (Kitot et al., 2010), bahwa model pembelajaran guided-inquiry efektif dalam meningkatkan kemampuan akademik siswa yaitu kemampuan berpikir kritis (Wartono et al., 2018) sehingga harus diterapkan di sekolah. Model pembelajaran guided-inquiry juga dapat meningkatkan keterampilan memecahkan masalah, kemampuan berpikir kreatif dalam aspek kelancaran, fleksibilitas, orisinalitas dan elaborasi (Serevina, Andriana, \& Fernandianto, 2018); (Simanjuntak et al., 2019).

Efektivitas model pembelajaran guided-inquiry dalam meningkatkan kemampuan berpikir kritis siswa dan keterampilan memecahkan masalah, perlu ditinjau dan diuji secara empirik untuk konsistensi lebih lanjut dalam meningkatkan kemampuan berpikir kritis dan keterampilan memecahkan masalah biologi siswa SMA Indonesia. Penelitian ini sangat penting untuk mengembangkan model dan teori pembelajaran yang mampu menjawab tantangan dan kebutuhan keterampilan di abad ke-21.

\section{METODE}

Penelitian ini termasuk dalam penelitian eksperimen. Jenis penelitian yaitu eksperimen semu atau kuasi eksperimen menggunakan desain posttest only design dengan tujuan untuk mengukur efektivitas model pembelajaran guided-inquiry dalam meningkatkan kemampuan berpikir kritis dan keterampilan memecahkan masalah materi perubahan lingkungan. Penelitian berlangsung menggunakan dua kelompok belajar, yaitu kelompok eksperimen dan kelompok kontrol. Kelompok eksperimen diberikan perlakuan menggunakan model pembelajaran guided-inquiry dan kelompok kontrol menggunakan model pembelajaran konvensional yang biasa digunakan guru dalam proses pembelajaran. Desain penelitian dapat dilihat pada tabel 1 .

Tabel 1. Desain Penelitian

\begin{tabular}{cccc}
\hline No. & Kelas & Perlakuan & Post Test \\
\hline \multirow{2}{*}{1} & \multirow{2}{*}{ Eksperimen } & \multirow{2}{*}{$X_{1}$} & $O_{1}$ \\
\cline { 4 - 4 } 2 & \multirow{2}{*}{ Kontrol } & \multirow{2}{*}{$X_{2}$} & $O_{2}$ \\
\cline { 3 - 4 } & & & $O_{1}$ \\
\hline
\end{tabular}

Keterangan:

$O_{1}$ : Posttest Kemampuan Berpikir Kritis.

$\mathrm{O}_{2}$ : Posttest Observasi Keterampilan Memecahkan Masalah.

$X_{1}$ : Pembelajaran menggunakan Model Pembelajaran Guided-inquiry.

$X_{2}$ : Pembelajaran menggunakan Model Pembelajaran Konvensional.

Penelitian dilaksanakan di SMAN 2 Ngaglik, Kabupaten Sleman, Daerah Istimewa Yogyakarta pada semester genap tahun pelajaran 2018/2019. Penelitian berlangsung di kelas X MIPA pada bulan Maret-April 2019 dengan menggunakan materi perubahan lingkungan. Populasi dalam penelitian ini yaitu 127 siswa, dengan rincian 63 siswa di kelas eksperimen yang akan belajar materi perubahan lingkungan dengan menggunakan model pembelajaran guided-inquiry dan 64 siswa di kelas kontrol yang belajar dengan menggunakan model pembelajaran konvensional. Sampel yang dipilih harus mewakili populasi yang ada dalam penelitian. Sampel dipilih dengan menggunakan teknik random sampling.

Pengumpulan data yang dilakukan dalam penelitian dengan mengadakan observasi keterampilan memecahkan masalah dan tes kemampuan berpikir kritis. Observasi keterampilan memecahkan masalah dilakukan saat proses pembelajaran (penyelidikan) berlangsung dengan mengamati aktivitas siswa, sedangkan pengumpulan data kemampuan berpikir kritis dilakukan dengan menggunakan tes keterampilan berpikir kritis, dalam bentuk posttest saat semua perlakuan dalam pembelajaran sudah dilakukan. Data hasil penelitian kemudian dianalisis menggunakan aplikasi windows IBM Statistik SPSS 23.0 dengan menggunakan uji Manova. 


\section{HASIL}

Berdasarkan hasil analisis data untuk mencari ada tidaknya perbedaan perlakuan terhadap kemampuan berpikir kritis dan keterampilan memecahkan masalah dapat dilakukan apabila sudah memenuhi beberapa asumsi Manova. Beberapa asumsi yang harus dipenuhi sebelum dilakukan uji Manova adalah normalitas, homogenitas, korelasi (Stevens, 2009). Hasil uji asumsi Manova dapat dilihat pada tabel 2, 3, dan 4 .

Tabel 2. Tests of Normality

\begin{tabular}{lcccccc}
\hline & \multicolumn{2}{c}{ Kolmogorov-Smirnov $^{\text {a }}$} & \multicolumn{3}{c}{ Shapiro-Wilk } \\
\cline { 2 - 7 } & Statistic & df & Sig. & Statistic & df & Sig. \\
\hline KBK Eks 1 & 0,084 & 63 & 0,200 & 0,969 & 63 & 0,118 \\
KBK Eks 2 & 0,069 & 64 & 0,200 & 0,984 & 64 & 0,572 \\
KMM Eks 1 & 0,106 & 63 & 0,073 & 0,967 & 63 & 0,090 \\
KMM Eks 2 & 0,102 & 64 & 0,167 & 0,963 & 64 & 0,057 \\
\hline
\end{tabular}

Berdasarkan hasil uji normalitas data tes kemampuan berpikir kritis dan observasi keterampilan memecahkan masalah materi perubahan lingkungan, dapat disimpulkan bahwa kedua data untuk masing-masing kelas penelitian yang menerapkan model pembelajaran guided-inquiry dan model pembelajaran konvensional berada pada distribusi normal karena nilai signifikansi yang diperoleh > 0,05 (taraf signifikansi) baik pada uji Kolmogorov-Smirnov dan Shapiro Wilk.

Pada tabel 3 ditampilkan hasil analisis homogenitas data. Analisis homogenitas data menggunakan Box's M untuk melihat kesamaan matriks varians-kovarians antar grup pada variabel terikat. Berdasarkan hasil analisis, nilai signifikansi yang didapat adalah sebesar 0,133>0,05 (taraf signifikansi) sehingga dapat disimpulkan bahwa terdapat kesamaan matriks varianskovarians atau homogenitas data terpenuhi yaitu sebaran datanya merata.

Tabel 3. Box's M

\begin{tabular}{lr}
\hline Box's M & 5,690 \\
\hline F & 1,864 \\
df1 & 3 \\
df2 & 2835244,870 \\
Sig. & 0,133 \\
\hline
\end{tabular}

Selain uji asumsi normalitas dan homogenitas varians-kovarians, uji asumsi yang diuji sebelum dilakukan uji Manova untuk mengukur perbedaan kemampuan berpikir kritis dan keterampilan memecahkan masalah yang diterapkan model pembelajaran guided-inquiry dan model pembelajaran konvensional adalah uji korelasi menggunakan pearson correlation. Berdasarkan hasil analisis korelasi pada tabel 4, nilai pearson correlation yang diperoleh sebesar 0,377> taraf signifikansi $(0,05)$ sehingga dapat disimpulkan bahwa ada hubungan antara kemampuan berpikir kritis dan keterampilan memecahkan masalah materi perubahan lingkungan. Setelah semua uji asumsi terpenuhi, maka uji Manova dapat dilakukan untuk menguji perbedaan penerapan model pembelajaran guided-inquiry dan model pembelajaran konvensional terhadap kemampuan berpikir kritis dan keterampilan memecahkan masalah. Hasil uji Manova dapat dilihat pada tabel 5.

Tabel 4. Correlations

\begin{tabular}{llcc}
\hline & & KBK & KMM \\
\hline KBK & Pearson Correlation & 1 & $0,377^{* * *}$ \\
& Sig. (2-tailed) & & 0,000 \\
& N & 127 & 127 \\
\cline { 2 - 3 } KMM & Pearson Correlation & $0,377^{* *}$ & 1 \\
& Sig. (2-tailed) & 0,000 & \\
& N & 127 & 127 \\
\hline
\end{tabular}

Tabel 5. Multivariate Test Results

\begin{tabular}{clcccc}
\hline & Value & F & Hypothesis df & Sig. \\
\hline \multirow{2}{*}{ Kelompok } & Pillai's trace &, 282 & $24,377^{\mathrm{a}}$ & 2,000 &, 000 \\
Wilks' lambda &, 718 & $24,377^{\mathrm{a}}$ & 2,000 &, 000 \\
Hotelling's trace &, 393 & $24,377^{\mathrm{a}}$ & 2,000 &, 000 \\
Roy's largest root &, 393 & $24,377^{\mathrm{a}}$ & 2,000 &, 000 \\
\hline
\end{tabular}


Berdasarkan hasil analisis pada tabel 5, nilai signifikansi yang akan digunakan adalah Hotteling's Trace. Digunakannya uji statistik Hotteling's Trace karena dalam penelitian uji asumsi normalitas, homogenitas dan hanya terdapat dua kelompok variabel independen. Nilai signifikansi Hotteling's Trace yang diperoleh adalah sebesar $0,000<$ nilai signifikansi $(0,05)$ sehingga dapat disimpulkan bahwa ada perbedaan penerapan model pembelajaran guided-inquiry dan model pembelajaran konvensional dalam meningkatkan kemampuan berpikir kritis dan keterampilan memecahkan masalah materi perubahan lingkungan. Perbedaan peningkatan kemampuan berpikir kritis dan keterampilan memecahkan masalah kimia materi laju reaksi kelas eksperimen dan kelas kontrol yang menerapkan model pembelajaran berbeda dapat dilihat pada gambar 1 dan 2 .

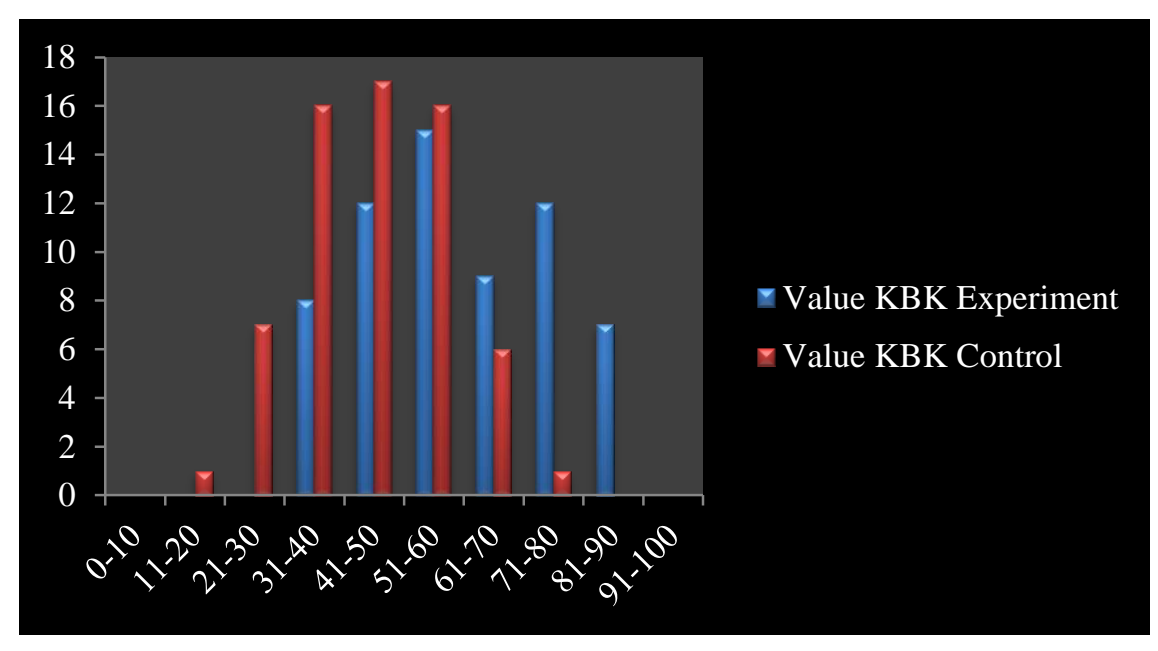

Gambar 1. Sebaran Nilai Tes Kemampuan Berpikir Kritis

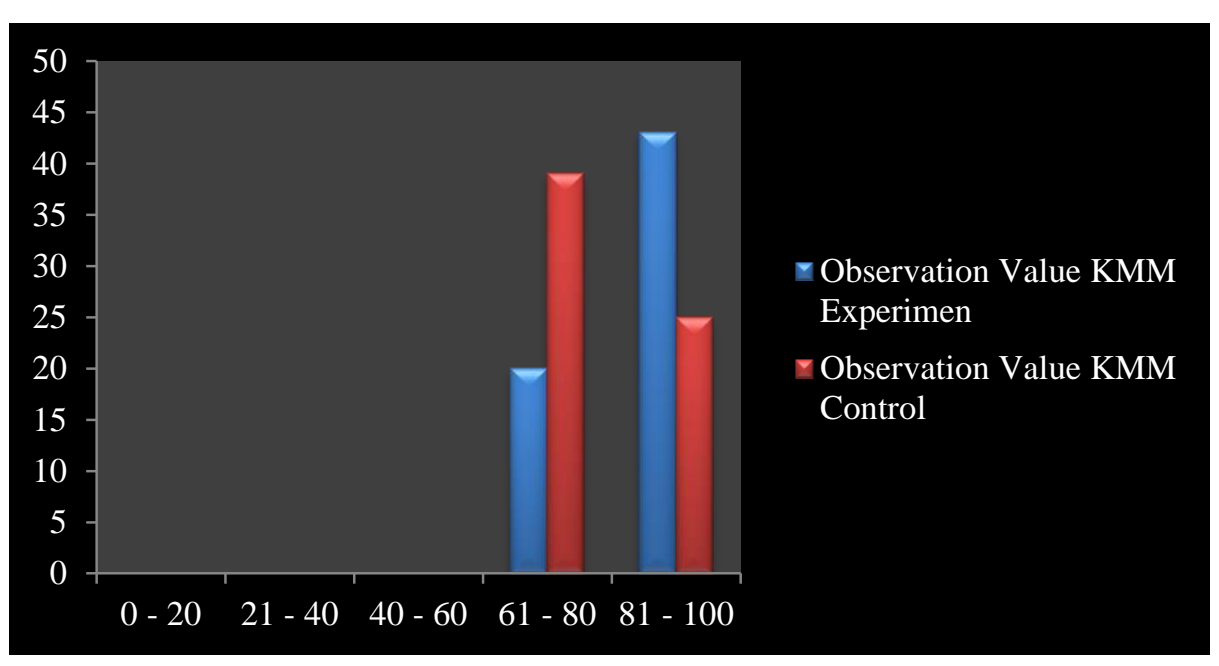

\section{Gambar 2. Sebaran Nilai Keterampilan Memecahkan Masalah}

Sebaran nilai kemampuan berpikir kritis kelas eksperimen dan kelas kontrol (Gambar 1), dapat dilihat bahwa kemampuan berpikir kritis siswa kelas eksperimen lebih baik dibandingkan dengan siswa kelas kontrol. Selain itu, sebaran nilai kemampuan berpikir kritis siswa kelas eksperimen banyak tersebar pada rentang nilai yang tinggi dibandingkan dengan siswa kelas kontrol.

Selain sebaran nilai kemampuan berpikir kritis, pada gambar 2 juga terdapat sebaran nilai keterampilan memecahkan masalah. Berdasarkan sebaran nilai keterampilan memecahkan masalah, dapat dianalisis bahwa siswa yang berada pada kelas eksperimen yang menerapkan model pembelajaran guided-inquiry memiliki keterampilan memecahkan masalah yang lebih baik dibandingkan dengan siswa di kelas kontrol yang belajar menggunakan model pembelajaran konvensional. 


\section{PEMBAHASAN}

Berdasarkan hasil penelitian ini, menunjukkan bahwa kemampuan berpikir kritis dan pemecahan masalah materi perubahan lingkungan pada kelas eksperimen yang menggunakan model guided inquiry memiliki perbedaan dengan kemampuan berpikir kritis dan pemmecahan masalah pada kelas kontrol yang menggunakan model pembelajaran konvensional. Kelas eksperimen memiliki sebaran nilai kemampuan berpikir kritis dan kemampuan pemecahan masalah yang lebih tinggi daripada kelas kontrol. Pada kelas eksperimen dengan menggunakan model guided inquiry, siswa belajar dengan melakukan kegiatan penyelidikan tentang perubahan lingkungan secara aktif daripada siswa pada kelas kontrol. Kegiatan penyelidikan pada kelas eksperimen ini memberi ruang bagi siswa untuk membangun kemampuannya melalui bukti empiris tentang perubahan lingkungan yang secara langsung berkaitan dengan pengalaman yang dialami. Sejalan dengan hasil penelitian ini (Brew, 2012) menyatakan bahwa proses belajar yang berkaitan secara langsung dengan kegiatan penyelidikan akan membantu siswa dalam meningkatkan keterampilan berpikir kritisnya. Selain itu, dengan kegiatan penyelidikan juga dapat membantu keterampilan siswa dalam menghadapi dan memecahkan masalah kehidupan yang dihadapinya (Koksal \& Berberoglu 2014). Selain itu, dengan model guided-inquiry, siswa dapat menyimpan informasi lebih lama daripada siswa yang belajar menggunakan pembelajaran yang konvensional (Vanags, Pammer, \& Brinker, 2013). Model pembelajaran guided inquiry memudahkan siswa dalam belajar karena siswa sendiri terlibat langsung dan aktif (Arslan, 2014), dan guru sebagai fasilitator mendorong siswa untuk memiliki pengalaman eksperimen dan perilaku yang memungkinkan siswa dalam menemukan konsep-konsep atau prinsip-prinsip tanpa memerlukan bantuan guru (Brew, 2012); (MacKay \& Wetzel, 2014).

Model pembelajaran guided-inquiry perlu digunakan dalam proses pembelajaran untuk membuat siswa aktif dalam kegiatan pembelajaran sehingga siswa dapat terlibat dalam proses pemikiran yang mendalam yang akan membantu untuk memecahkan masalah yang terjadi dalam belajar mandiri (Carneiro et al., 2016). Proses pembelajaran model ini juga menuntun siswa bekerja dalam kelompok kecil (Vanags et al., 2013) sehingga setiap anggota kelompok secara aktif menyelesaikan tugasnya masing-masing untuk saling membantu dalam memecahkan masalah bersama. Kegiatan kolaboratif dalam kelompok ini sangat membantu siswa dalam berbagi pikiran atau pendapat bersama-sama dalam memecahkan masalah, dan juga siswa diajarkan untuk bertanggung jawab terhadap tugas yang diberikan.

Ada perbedaan dalam kemampuan berpikir kritis dan pemecahan masalah pada kelas eksperimen dan kelas kontrol. Proses pembelajaran model guided-inquiry berorientasi pada siswa, dimana siswa diberikan pertanyaan untuk membangkitkan motivasi untuk belajar, kemudian siswa diberi kesempatan untuk menjawab pertanyaan sementara yang telah diberikan guru, setelah memberikan jawaban sementara tersebut siswa diarahkan untuk mencari jawaban melalui studi literatur dan proses penyelidikan. Dalam proses ini, guru hanya berperan sebagai fasilitator untuk menemani dan membimbing siswa serta menyediakan berbagai sumber daya yang dapat mendukung proses pembelajaran tersebut. Proses pembelajaran dengan menggunakan model guided-inquiry di kelas eksperimen menunjukKan bahwa siswa sangat aktif dan antusias berpartisipasi dan rasa ingin tahu siswa semakin tinggi. Siswa termotivasi karena dalam proses penyelidikan, hal-hal yang biasanya mereka temukan dalam kehidupan sehari-hari di lingkungannya dan dapat dipelajari serta mereka mendapatkan jawaban mengapa hal tersebut dapat terjadi.

\section{SIMPULAN}

Berdasarkan hasil penelitian yang telah dilakukan, maka dapat disimpulkan bahwa penerapan model pembelajaran guided-inquiry sangat efektif dalam meningkatkan kemampuan berpikir kritis dan pemecahan masalah materi perubahan lingkungan melalui pembelajaran yang aktif dan kolaboratif yang dialami siswa. Hal ini berdasarkan analisis data yang telah dilakukan menunjukkan bahwa terdapat perbedaan yang signifikan antara kelas eksperimen yang menggunakan model guided inquiry dengan kelas kontrol yang menggunakan model pembelajaran konvensional. Oleh karena itu, model guided-inquiry dapat diterapkan dalam proses pembelajaran untuk meningkatkan kemampuan berpikir kritis dan pemecahan masalah yang masih rendah di tingkatan SMA di Indonesia.

\section{DAFTAR RUJUKAN}

Arslan, A. (2014). Transition between Open and Guided Inquiry Instruction. Procedia - Social and Behavioral Sciences, 141, 407-412. https://doi.org/10.1016/j.sbspro.2014.05.071

Brew, A. (2012). Teaching and research: New Relationships and Their Implications for Inquiry-Based Teaching and Learning in Higher Education. Higher Education Research and Development, 31(1), 101-114. https://doi.org/10.1080/07294360.2012.642844

Carneiro, G., Parulekar, T., Shridhar, G., \& Ladage, S. (2016). Experimenting with the Teaching of Organic Chemistry - The Process-Oriented Guided Inquiry Learning Way. Current Science, 111(7), 1152-1155. https://doi.org/10.18520/cs/v111/i7/1152-1155

Chase, A., Pakhira, D., \& Stains, M. (2013). Implementing Process-Oriented, Guided-Inquiry Learning for the First Time: Adaptations and Short-Term Impacts on Students' Attitude and Performance. Journal of Chemical Education, 90(4), 409416. https://doi.org/10.1021/ed300181t 
Conway, C. J. (2014). Effects of Guided Inquiry Versus Lecture Instruction on Final Grade Distribution in a One-Semester Organic and biochemistry course. Journal of Chemical Education, 91(4), 480-483. https://doi.org/10.1021/ed300137z

Domin, D. S. (1999). A review of laboratory instruction styles. Journal of Chemical Education, 76(4), 543-547.

Douglas, E. P., \& Chiu, C.-C. (2012). Process-Oriented Guided Inquiry Learning in Engineering. Procedia - Social and Behavioral Sciences, 56(Ictlhe), 253-257. https://doi.org/10.1016/j.sbspro.2012.09.652

Greiff, S., Holt, D. V., \& Funke, J. (2013). Perspectives on Problem Solving in Educational Assessment: Analytical, Interactive, and Collaborative Problem Solving. The Journal of Problem Solving, 5(2). https://doi.org/10.7771/1932-6246.1153

Hein, S. M. (2012). Positive Impacts Using POGIL in Organic Chemistry. Journal of Chemical Education, 89(7), 860-864. https://doi.org/10.1021/ed100217v

Hmelo-Silver, C. E., Duncan, R. G., \& Chinn, C. A. (2007). Scaffolding and Achievement in Problem-Based and Inquiry Learning: A Response to Kirschner, Sweller, and Clark (2006). Educational Psychologist, 42(2), 99-107. https://doi.org/10.1080/00461520701263368

Jatmiko, B., Prahani, B. K., Munasir, Supardi, Z. A. I., Wicaksono, I., Erlina, N., ... Zainuddin. (2018). The Comparison of Oripa Teaching Model and Problem Based Learning Model Effectiveness to Improve Critical Thinking Skills of PreService Physics Teachers. Journal of Baltic Science Education, 17(2), 300-319.

Kitot, A. K. A., Ahmad, A. R., \& Seman, A. A. (2010). The Effectiveness of Inquiry Teaching in Enhancing Students' Critical Thinking. Procedia - Social and Behavioral Sciences, 7(C), 264-273. https://doi.org/10.1016/j.sbspro.2010.10.037

Koksal, E. A., \& Berberoglu, G. (2014). The Effect of Guided-Inquiry Instruction on $6^{\text {th }}$ Grade Turkish Students' Achievement, Science Process Skills, and Attitudes Toward Science. International Journal of Science Education, 36(1), 66-78. https://doi.org/10.1080/09500693.2012.721942

Lopez, E. J., Shavelson, R. J., Nandagopal, K., Szu, E., \& Penn, J. (2014). Factors Contributing to Problem-Solving Performance in First-Semester Organic Chemistry. Journal of Chemical Education, 91(7), 976-981. https://doi.org/10.1021/ed400696c

MacKay, J. A., \& Wetzel, N. R. (2014). Exploring the Wittig Reaction: A Collaborative Guided-Inquiry Experiment for the Organic Chemistry Laboratory. Journal of Chemical Education, 91(5), 722-725. https://doi.org/10.1021/ed3003836

Mundilarto. (2012). Effect of Problem-Based Learning on Improvement Physics Achievement and Critical Thinking of Senior High School Student. Journal of Baltic Science Education, 16(0), 761-779.

Nariman, N., \& Chrispeels, J. (2015). PBL in the Era of Reform Standards: Challenges and Benefits Perceived by Teachers in One Elementary School. Interdisciplinary Journal of Problem-Based Learning, 10(1). https://doi.org/10.7771/15415015.1521

Noh, T., Jeon, K., \& Huffman, D. (2009). The Effects of Thinking A Loud Pair Problem Solving on High School Students' Chemistry Problem-Solving Performance and Verbal Interactions. Journal of Chemical Education, 82(10), 1558. https://doi.org/10.1021/ed082p1558

Özyurt, Ö. (2015). Examining the Critical Thinking Dispositions and the Problem Solving Skills of Computer Engineering Students. Eurasia Journal of Mathematics, Science and Technology Education, 11(2), 353-361. https://doi.org/10.12973/eurasia.2015.1342a

Rodzalan, S. A., \& Saat, M. M. (2015). The Perception of Critical Thinking and Problem Solving Skill among Malaysian Undergraduate Students. Procedia - Social and Behavioral Sciences, 172(2012), 725-732. https://doi.org/10.1016/j.sbspro.2015.01.425

Serevina, V., Andriana, W., \& Fernandianto, A. (2018). Improving Creative Thinking Ability of Class X Students Public High School 59 Jakarta through Guided Inquiry Learning Model. American Journal of Educational Research, 6(12), 15931599. https://doi.org/10.12691/education-6-12-1

Shishigu, A., Hailu, A., \& Anibo, Z. (2018). Problem-Based Learning and Conceptual Understanding of College Female Students in Physics. Eurasia Journal of Mathematics, Science and Technology Education, 14(1), $145-154$. https://doi.org/10.12973/ejmste/78035

Simanjuntak, D., Elvis Napitupulu, E., Manullang, M., Manalu, R., \& Sinambela, L. (2019). The Enhancement Difference of Student Mathematical Problem Solving Ability between Guided Discovery Learning Model and Direct Learning Model. American Journal of Educational Research, 6(12), 1688-1692. https://doi.org/10.12691/education-6-12-15

Stephenson, N. S., \& Sadler-Mcknight, N. P. (2016). Developing Critical Thinking Skills Using the Science Writing Heuristic in the Chemistry Laboratory. Chemistry Education Research and Practice, 17(1), 72-79. https://doi.org/10.1039/c5rp00102a

Tan, O. S. (2003). Problem-Based Learning Innovation: Using Problems to Power Learning in the $21^{\text {st }}$ Century. GALE Cengage Learning.

Vanags, T., Pammer, K., \& Brinker, J. (2013). Process-Oriented Guided-Inquiry Learning Improves Long-Term Retention of Information. Advances in Physiology Education, 37(3), 233-241. https://doi.org/10.1152/advan.00104.2012

Wartono, W., Hudha, M. N., \& Batlolona, J. R. (2018). How are the Physics Critical Thinking Skills of the Students Taught by Using Inquiry-Discovery Through Empirical and Theorethical Overview? Eurasia Journal of Mathematics, Science and Technology Education, 14(2), 691-697. https://doi.org/10.12973/ejmste/80632 
851 Jurnal Pendidikan, Vol. 5, No. 6, Bln Juni, Thn 2020, Hal 844—851

Yu, K. C., Lin, K. Y., \& Chang, S. F. (2017). The Development and Validation of a Mechanical Critical Thinking Scale for High School Students. Eurasia Journal of Mathematics, Science and Technology Education, 13(5), 1361-1376. https://doi.org/10.12973/eurasia.2017.00675a 